\title{
Assessing Spatial and Temporal Trends in a Mediterranean Fish Assemblage Structure
}

\author{
Michel Marengo ${ }^{1,2, * \mathbb{D}}$, Laura Iborra ${ }^{1,2,3}$, Michèle Leduc ${ }^{1}$, Pierre Lejeune ${ }^{1}$, Pierre Boissery ${ }^{4}$ \\ and Sylvie Gobert 1,2 (D)
}

1 Station de Recherches Sous-marines et Océanographiques (STARESO), Punta Revellata, BP33, 20260 Calvi, France; laura.iborra@stareso.com (L.I.); m.leduc@stareso.com (M.L.); p.lejeune@stareso.com (P.L.); sylvie.gobert@uliege.be (S.G.)

2 Laboratoire d'Océanologie, Centre MARE, Université de Liège, Sart-Tilman, B6c, 4000 Liège, Belgium

3 Institut Méditerranéen d'Océanologie (M.I.O), Campus de Luminy, 163 Avenue de Luminy—OCEANOMED, CEDEX 09, 13288 Marseille, France

4 Agence de l'Eau Rhône Méditerranée Corse-Délégation Paca Corse, Immeuble Le Noailles, 62 La Canebière, 13001 Marseille, France; Pierre.BOISSERY@eaurmc.fr

* Correspondence: michel.marengo@stareso.com

Citation: Marengo, M.; Iborra, L.; Leduc, M.; Lejeune, P.; Boissery, P.; Gobert, S. Assessing Spatial and Temporal Trends in a Mediterranean Fish Assemblage Structure. Diversity 2021, 13, 368. https://doi.org/ $10.3390 / \mathrm{d} 13080368$

Academic Editors: Carlo Nike Bianchi and Carla Morri

Received: 2 July 2021

Accepted: 6 August 2021

Published: 9 August 2021

Publisher's Note: MDPI stays neutral with regard to jurisdictional claims in published maps and institutional affiliations.

Copyright: (c) 2021 by the authors. Licensee MDPI, Basel, Switzerland. This article is an open access article distributed under the terms and conditions of the Creative Commons Attribution (CC BY) license (https:// creativecommons.org/licenses/by/ $4.0 /)$.

\begin{abstract}
Coastal fishes are not only valuable elements of marine biodiversity, but they also play an important ecological role in the functioning of coastal ecosystems: food resource, transfer of nutrients, predators. Therefore, data on the compositions of fish assemblages are of great importance. The objectives of the present study were to (i) define the faunistic characteristics of a typical fish community on the Mediterranean coast; (ii) investigate spatiotemporal changes in fish assemblages. Based on a set of indices (Fast protocol) and a long-term data set (6 years, 612 visual counts, $154 \mathrm{~h}$ of diving), changes in coastal fish communities were analyzed. Our results indicated that there was a significant shift in fish community structure, with a general decline of the calculated indices. In our study, part of the observed variability in fish assemblage structure could be due to different factors as site location and sampled year. The changes in the fish assemblages associated with inter-annual fluctuations observed in this study also provide important insights into how fish communities may change under environmental and anthropogenic influences.
\end{abstract}

Keywords: fisheries; fish assemblage; marine protected area; visual census

\section{Introduction}

For millions of people in the Mediterranean, seafood is an important food resource that has ensured their livelihood over the centuries; however, this resource is threatened by local and global impacts. Out of the 519 native marine fish species and subspecies included in the International Union for the Conservation of Nature (IUCN) regional assessment for the Mediterranean Sea, more than $8 \%$ (43 species) are classified in threatened categories (critically endangered, endangered, or vulnerable) [1]. In many marine communities, changes in faunal assemblages have been observed; these changes can be explained by environmental factors (temperature, salinity, $\mathrm{pH}$ ) and anthropogenic stressors, such as fishing (removal of key predators and pastures) [2], pollution [3], invasive species [4], and/or climate change [5]. These drivers can impact marine communities at different levels, from individual physiology and population-level changes (altering growth, reproductive capacity, and mortality) to community and ecosystem shifts (modifying productivity, structure, and composition) [6].

In this context, to better understand the structure and dynamics of marine populations, the study of species diversity and abundance is fundamental [7]. Coastal fishes are not only valuable elements of marine biodiversity, but they also play an important ecological role in the functioning of coastal ecosystems: food resource, transfer of nutrients, predators [8,9]. Therefore, data on the compositions of fish assemblages are of great importance [10]. 
For the assessment and monitoring of key fish assemblage characteristics, various techniques are being used to better understand the status and trends of fish populations [11]. Counting organisms is a basic and central component of ecology, management, and conservation [12]. A multitude of techniques have been used to collect quantitative data on the organization and abundance of fish, including underwater visual census (UVC): remote underwater video, baited video, acoustics, gillnets, traps, and various fishing methods [13]. Among the various sampling methods that have been in use since the 1950s, UVC is one of the most commonly applied methods for assessing the status of coastal fish communities [14]. Fishery-independent techniques, such as UVC, can be used to determine and quantify the species richness and abundance and fish distribution and sizes [15].

UVC is especially effective because it is one of the few non-destructive methods for collecting quantitative data on marine communities that include highly mobile species, such as fish [16]. A wide variety of UVC methods exists, such as stationary point counts, transects, and timed swims [17]. There are several advantages to this method: UVC is a non-size-selective, technically simple, and relatively inexpensive sampling technique [18]. UVC techniques are useful for characterizing a wide range of fish sizes and behaviors as well as habitat types (especially in architecturally complex habitats). Another important benefit is that they can be easily learned by divers, who may thereby simultaneously and rapidly record information on environmental variables [19]. These sampling methods (both targeting and not targeting fisheries taxa) have provided a better understanding of the ecological effects of fishery exploitation and environmental disturbance of coastal ecosystems [20]. UVC techniques are very flexible for field implementation of any sampling plan, allowing for a wide variety of ecological issues to be addressed [21].

Despite the many benefits and global use of UVC, some limitations and operational difficulties deserve attention [22]. Many biases have been identified and are well documented, such as the physiological constraints of scuba diving, diving time, fish activity, individual fish response (attraction or escape), and bias in the estimation of the abundance of cryptic, elusive, hidden, or small-sized fish [23]. For example, it is also known that UVC results are influenced by the complexity of the environment, the community richness, and the visibility [24]. Despite its limitations, UVC remains by far the most popular and reliable method available for investigating fish populations and supporting conservation and fishery management decisions [25].

The objectives of this study were to (i) define the faunistic characteristics (composition, structure, species richness) of a typical fish community on the Mediterranean coast; (ii) understand spatiotemporal changes in fish assemblages.

\section{Materials and Methods}

\subsection{Sampling Locations}

This study was conducted at the French Mediterranean coast, in the Calvi bay area (Corsica, Northwestern Mediterranean Sea). The study area included three sites off the Corsican coast: Revellata, Saint Francois, Spano, characterized by different geomorphological features and human pressures (Figure 1). All three sites were sampled to a maximum depth of $30 \mathrm{~m}$. The Revellata zone is an uneven and rocky area (presence of cavities, overhangs, slopes). It is located inside a classified Natura 2000 zone (FR9400574; FR9402018) and was considered a reference zone with high species biodiversity. Flora and fauna species belonging to remarkable genuses, such as Cystoseira, Epinephelus, and Palinurus, were frequently encountered there. There are rich natural areas, characterized by the presence of coralligenous, P. oceanica meadows, and infralittoral rocks with photophilic algae. Colonies of Eunicella and Parazoanthus colonized the slopes and overhangs, which made this zone rich and attractive to dive. As a result, it is a recognized dive site and is very popular with local clubs (peaks of up to 100 dives per day in summer). 

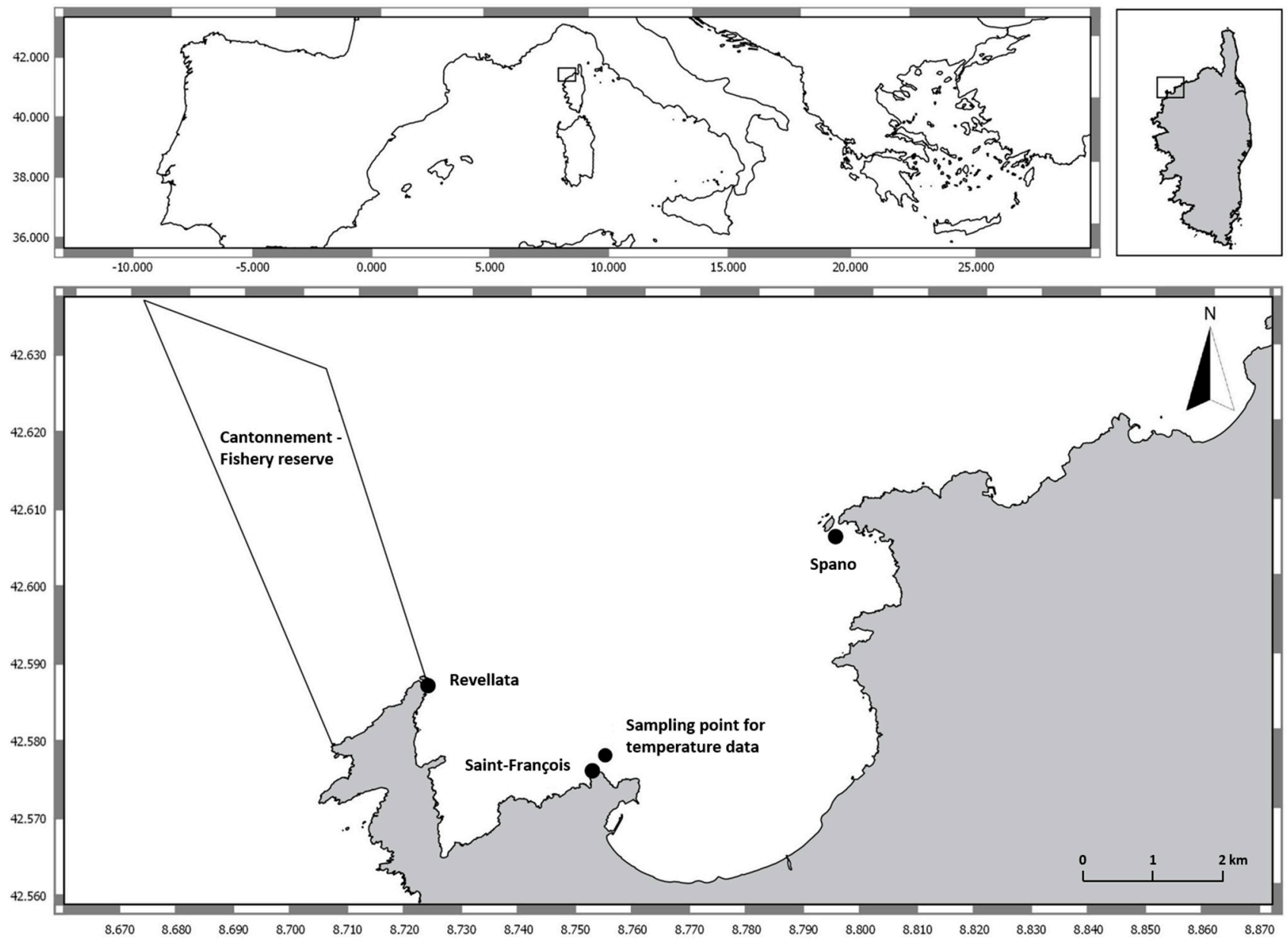

Figure 1. Sampling sites' locations in the Calvi Bay (Corsica, France): Revellata, Saint-Francois, Spano.

Spano is the zone that is the least impacted by urban activities, $5 \mathrm{~km}$ away from Calvi city center, with 5410 inhabitants. However, professional and recreational fishing activities are not negligible. It was classified as an attractive site for diving with an average level of richness of heritage species. Spano is a rocky site. These rocks are colonized by numerous coralligenous colonies at a depth of $30 \mathrm{~m}$, then mainly infralittoral rocks and P. oceanica meadows near the coast.

The Saint-François zone is located only a few hundred meters away from the urban area of Calvi. The bottoms are essentially areas of coastal detrital, but there is also the presence of areas of infralittoral rocks covered with algae and P. oceanica meadows. It is, therefore, directly influenced by the harbor area of Calvi and by sewer outfall discharges (mean daily flows $2965 \mathrm{~m}^{3}$ ). In addition, the proximity of the harbor is an asset for local dive clubs, who visit this site daily (more than 60 dives per day in summer). This site is therefore subject to significant anthropogenic pressure.

This study was conducted over a period of 6 years (2012 and 2017) between April and September. A total of $154 \mathrm{~h}$ in 612 visual counts were performed by scientific divers. To assess seasonal variation in diversity and abundance of the fish assemblages, sampling activities were carried out in spring (April, May, June) and summer (July, August, September).

\subsection{Fish Assemblage Sampling Technique (FAST)}

The Fish Assemblage Sampling Technique (FAST) is a UVC method designed for routine monitoring of coastal areas [26]. Indices calculated from data collected with FAST censuses can be used as proxies of variables describing the structure and composition (e.g., 
species richness, total density, size) of fish assemblages [10]. For each sampling site, the data collection consisted of a minimum of six replicates of $15 \mathrm{~min}$ visual scans, carried out at a depth between 10 and $25 \mathrm{~m}$, covering all kinds of substrata (sand, seagrass, rocky areas), along a random pathway using SCUBA diving. For each visual scan, the presence/absence of fish species from a pre-determined list (Table 1) and their size class were recorded. The 28 species selected (Table 1) include species that are targeted by professional and/or recreational fishers (e.g., net fishing, spearfishing, or angling), easily identified underwater, with largely non-cryptic lifestyle, and/or endangered species. Here, two size classes were considered: large fish, i.e., longer than two-thirds of the maximum body size of each species, and small fish, shorter than two-thirds of maximum size [26,27]. The maximum length of each species was obtained from fishbase.org. An index (I) was calculated and weighted according to species and size. "Key" species received a higher weight $(\times 2)$ than the rest $(\times 1)$. Key species were considered to be those with a high commercial or ecological value or those that are endangered (e.g., Epinephelus marginatus, Phycis phycis, Sciaena umbra). For several species, a single size class (the largest) was considered as key (e.g., for Dentex dentex, Sparus aurata, and Dicentrarchus labrax). Based on the 6 replicates, four indices were calculated as proxies of the structure of fish assemblages.

Table 1. List of species selected during the FAST sampling and trophic category (from fishbase.org).

\begin{tabular}{ccc}
\hline Fish Family & Species & Trophic Level \\
\hline Carangidae & Seriola dumerili & 4.5 \\
Congridae & Conger conger & 4.3 \\
Dasyatidae & Dasyatis spp. & 4.3 \\
Hippocampinae & Hippocampus spp. & 3.2 \\
Labridae & Labrus spp. & 3.9 \\
Sparidae & Diplodus annularis & 3.6 \\
& Diplodus cervinus & 3.0 \\
& Diplodus puntazzo & 3.2 \\
& Diplodus sargus & 3.4 \\
& Diplodus vulgaris & 3.5 \\
& Dentex dentex & 4.5 \\
& Lithognathus spp. & 3.4 \\
& Pagrus spp. & 3.9 \\
& Sarpa salpa & 2.0 \\
& Sparus aurata & 3.7 \\
Serranidae & Spondyliosoma cantharus & 3.3 \\
& Serranus scriba & 3.8 \\
& Epinephelus marginatus & 4.4 \\
Moronidae & Symphodus tinca & 3.3 \\
Mugilidae & Dicentrarchus labrax & 3.5 \\
Mullidae & Mugil spp. & 2.5 \\
Muraenidae & Mullus surmuletus & 3.5 \\
Myliobatidae & Muraena helena & 4.2 \\
Phycidae & Myliobatis spp. & 3.6 \\
Sciaenidae & Phycis spp. & 4.3 \\
Scorpaenidae & Sciaena umbra & 3.8 \\
Sphyraenidae & Scorpaena scrofa & 4.3 \\
& Sphyraena spp. & 4.0 \\
\hline
\end{tabular}

The carnivores' proportion (CP) is the average number of observed carnivorous species/individuals. Next to the small/medium-sized grouper (Epinephelus marginatus), which was considered as a carnivore, only large individuals with trophic level $>3.7$ were considered carnivores. The proportion of large individuals (LP) is the average number of large individuals observed in the same census. The mean index (MI) was computed as the average of the six index values and is a proxy for size classes occurrences and species density. The relative species richness (RSR) was calculated as the average number of species observed after pooling the six replicate visual scans per survey. For each site, the FAST 
indices were calculated as the arithmetic mean of the stations and expressed as percentages $(100 \%=$ theoretical maximum value). The four FAST indices were calculated as follows:

- Carnivore proportion $(\mathrm{CP})=$ Mean number of observed carnivores species;

- Proportion of large individuals (LP) = Mean number of large size individuals observed in the same census;

- Mean index (MI) = Mean number of six "Index" values based on six censuses;

- Relative Species Richness (RSR) = Mean number of species observed based on six censuses.

In order to complete this information, a coefficient of variation (CV) was then calculated from the values of the four indices obtained per station. It allowed for assessing the fish assemblage variability. If the coefficient of variation was greater than $30 \%$, this indicated a degradation of the fish population structure.

\subsection{Sea Water Temperature}

To establish the environmental baseline, seawater temperature was measured bimonthly from April to October between 2012 and 2017 during sea campaigns. The sampling point chosen was close to the three sampling stations $\left(42.573056^{\circ} \mathrm{N}, 8.757222^{\circ} \mathrm{E}\right)$ in order to provide representative values of the temperature regime conditions of the bay. Vertical profiles of temperature were performed with a conductivity, temperature, and depth probe (CTD) (Aanderaa, RCM9; YSI, Model 6600). During its immersion, the CTD recorded the water temperature every $0.5 \mathrm{~s}$, enabling the characterization of the water column vertical structure. The data collected were plotted using the Ocean Data View (ODV) software (a software package for the interactive exploration and graphical display of multiple parameters developed for oceanographic observations).

\subsection{Data Analyses}

Multivariate analyses were employed to assess differences in fish assemblage structure. The indices (CP, LP, MI, RSR) were separately analyzed using resemblance matrices based on Euclidean distances. All matrices were analyzed through a three-way permutational analysis of variance (PERMANOVA), using "Location" as a random variable, with three levels: Revellata, Saint Francois, and Spano, "Season" as a random variable with two levels: spring, summer, and "Year" as a random variable with, six levels: 2012, 2013, 2014, 2015, 2016 and 2017.

Spearman rank correlation tests were used to compare (i) relative species richness, (ii) proportion of large individuals, (iii) proportion of carnivores, and (iv) mean index with bottom seawater temperature. The average depth of the census was approximately $20 \mathrm{~m}$ deep. The average water temperature at $20 \mathrm{~m}$ depth from the CTD data was used to perform the correlation tests. The objective was to assess the effect of temperature on fish abundance based on the frequency of observation.

\section{Results}

During the sampling, of the 28 selected species, on average by count there were 16 , 15 and 13 different species recorded at the sites of Revellata, Saint-Francois, and Spano, respectively. The proportion of carnivores, size structure, and species richness of fish assemblages differed between zones and years. The PERMANOVA tests on the four indices (MI, RSR, CP, LP) revealed that there were significant differences between zones and years $(p$-value $=0.001$, for all, Table 2). No significant seasonal differences were observed for the four indices ( $p$-value $\geq 0.05$, for all). Concerning the RSR, CP, and LP indices, a significant Zone*Year-level interaction was detected. Similarly, interactions between Zone*Season and Year*Season were detected, but only for the RSR index. For the other three indices (CP, LP, $\mathrm{MI}$ ), no interactions were highlighted (Table 2). Significant differences between zones were observed. The highest MI values were observed at Revellata, followed by Saint-Francois, followed by Spano (Figure 2). The same trend was recorded for the CP and LP values. The Revellata zone had the highest proportion of carnivores, larger fish, and a more diverse fish 
community than the other two zones (Figure 2). Conversely, the highest RSR values were observed at Saint-Francois, followed by Revellata, followed by Spano. In terms of RSR values, there was a significant difference between Revellata or Saint-Francois and Spano.

Table 2. PERMANOVA applied on FAST census to assess differences in fish assemblage structure. The indices Carnivores Proportion (CP), Large Proportion (LP), Mean Index (MI), and Relative Species Richness (RSR) were separately analyzed using resemblance based on Euclidean distance. ${ }^{*} p<0.05 ;{ }^{* *} p<0.01$; ${ }^{* *} p<0.001$.

\begin{tabular}{cccccccccc}
\hline FAST & Indices & \multicolumn{2}{c}{ MI } & \multicolumn{2}{c}{ RSR } & \multicolumn{2}{c}{ CP } & \multicolumn{2}{c}{ LP } \\
\hline Sources & Df & MS & P (perm) & MS & P (perm) & MS & P (perm) & MS & P (perm) \\
\hline Zone & 2 & 564.240 & $0.001^{* * *}$ & 473.650 & $0.001^{* * *}$ & 1926.600 & $0.001^{* * *}$ & 537.440 & $0.001^{* * *}$ \\
\hline Year & 5 & 446.770 & $0.001^{* * *}$ & 424.370 & $0.001^{* * *}$ & 454.870 & $0.001^{* * *}$ & 1055.200 & $0.001^{* * *}$ \\
\hline Season & 1 & 2.394 & 0.656 & 21.815 & 0.333 & 45.692 & 0.067 & 2.377 & 0.757 \\
\hline Zone $\times$ Year & 10 & 27.617 & 0.060 & 142.620 & $0.001^{* * *}$ & 87.420 & $0.001^{* * *}$ & 68.504 & $0.007^{* *}$ \\
\hline Zone $\times$ Season & 2 & 28.966 & 0.152 & 82.035 & $0.042^{* *}$ & 9.980 & 0.491 & 37.043 & 0.221 \\
\hline Season $\times$ Year & 5 & 14.528 & 0.438 & 147.530 & $0.001^{* * *}$ & 32.945 & 0.070 & 24.189 & 0.430 \\
\hline $\begin{array}{c}\text { Zone } \times \text { Year } \times \\
\text { Season }\end{array}$ & 7 & 9.596 & 0.695 & 38.115 & 0.170 & 12.862 & 0.462 & 7.395 & 0.944 \\
\hline Res & 75 & 14.348 & & 24.431 & & 13.858 & & 23.752
\end{tabular}
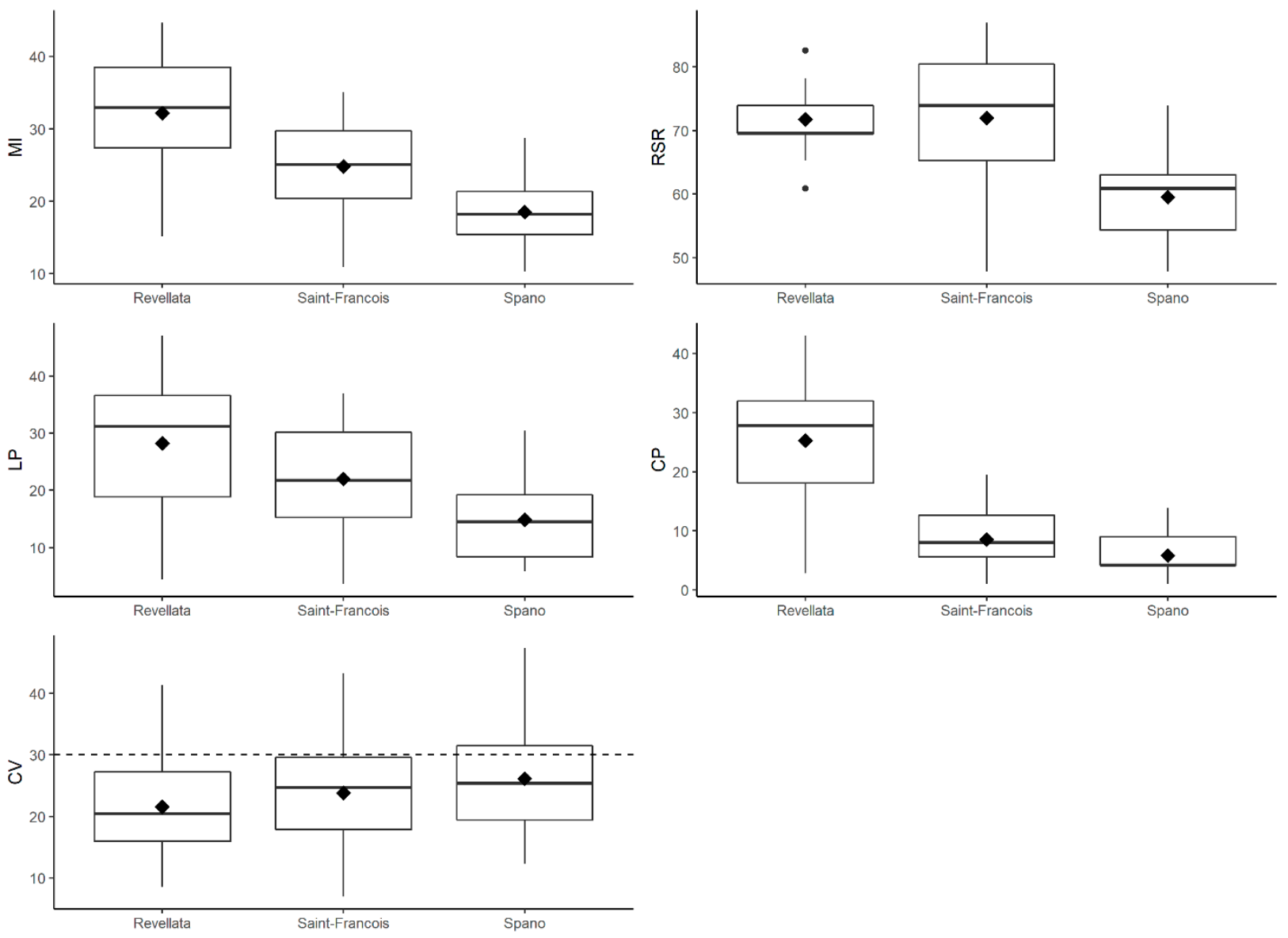

Figure 2. Spatial evolution of FAST results (CP, LP, MI, RSR) between 2012 and 2017 in the Saint-Francois, Spano, and Revellata zones. 
Annual fluctuations in the FAST indices were observed in the three zones. The trend of the four indices between 2012 and 2017 in relation to the factors "Zone" and "Year" is presented in Figure 3. The PERMANOVA pairwise comparison between the different years sampled revealed a significant decrease in the MI, LP, and CP indices over time. A temporal decline in the indices MI, LP, and CP was observed for all zones (Figure 3). For example, in Saint-Francois and Revellata, LP declined by 67\% and 64\% from 2012 to 2017, respectively. RSR values for the Spano and Revellata zones were relatively stable and did not exhibit any marked differences; however, a dramatic decrease was observed from 2015 (81.30) to 2017 (59.13) in the Saint-Francois zone.
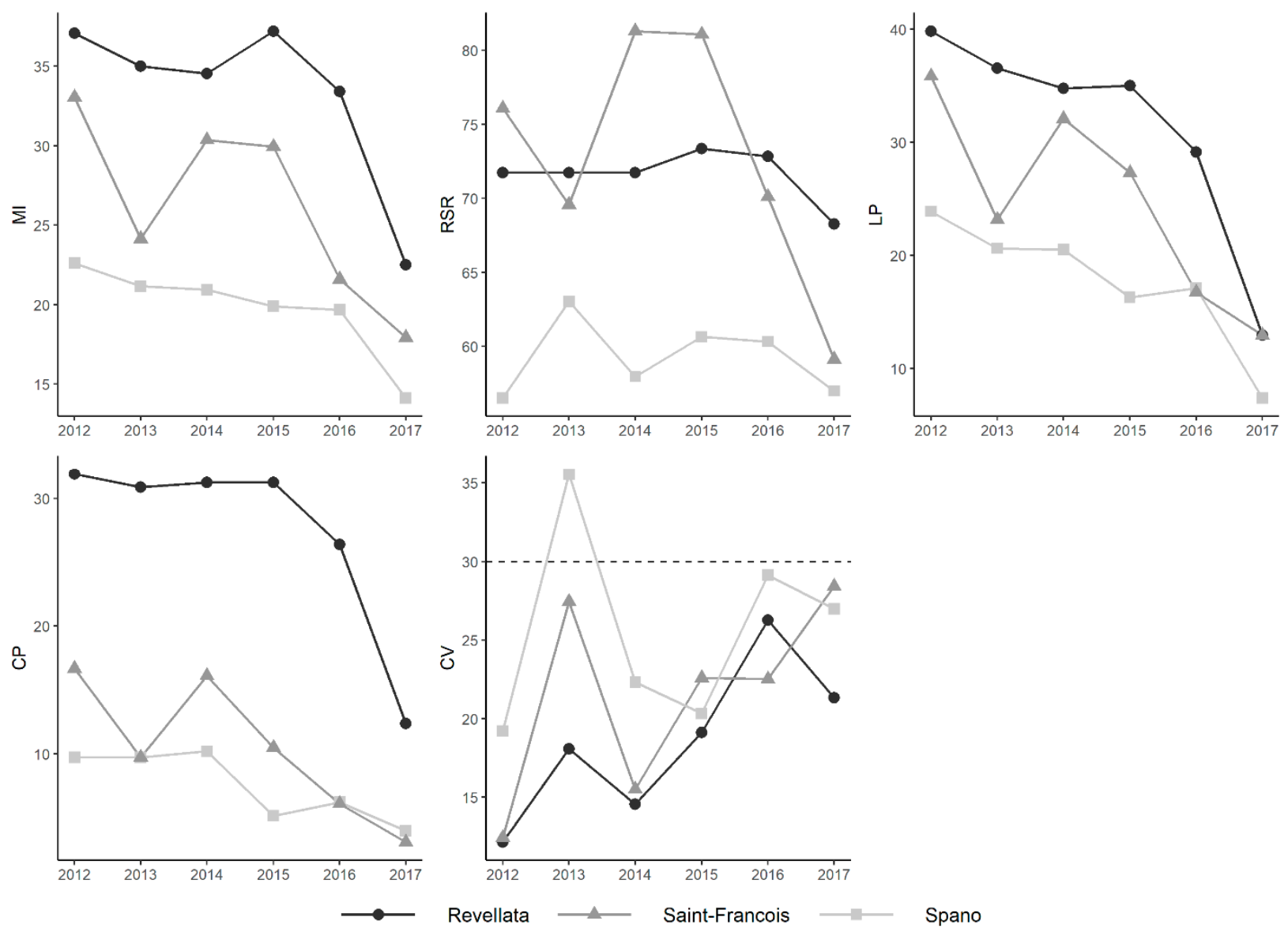

Figure 3. Temporal evolution of FAST results (CP, LP, MI, RSR) between 2012 and 2017 in the Saint-Francois, Spano, and Revellata zones.

For all three zones, we observed that the CV values increased from 12.15, 12.43 and 19.21 in 2012 to 21.33, 28.42 and 26.98 in 2017 in the Revellata zone, the Saint-Francois zone, and the Spano zone, respectively. All CVs calculated were lower than $30 \%$, except in one case: in the Spano zone in 2013 (35.58), the CV index was higher than 30\%, reflecting a significant heterogeneity of species assemblages over time. In Revellata, Spano and Saint-Francois, CV increased by 75\%, 40\% and $128 \%$ from 2012 to 2017, respectively.

During the study, sea surface temperatures ranged from a minimum of $12.7^{\circ} \mathrm{C}$ in April 2013 to a maximum of $27.3{ }^{\circ} \mathrm{C}$ in July 2015 (Figure 4). The temperature data indicated that the extent of warm temperature exposure $\left(\geq 20^{\circ} \mathrm{C}\right)$ at a depth between 20 and $30 \mathrm{~m}$ in 2016 and 2017 (135 days and 138 days, respectively) was much more prolonged than the mean value observed for the other years (2012-15, 101 days; Figure 5). These results highlight a strong positive thermal anomaly in 2016 and 2017, and thermal stratification of the water column was observed. The stratification of the water column started in early May and became stronger as summer progressed, with the temperature gradient increasing 
in strength in July and August (Figure 4). During the maximum stratification period, with surface temperatures above $23^{\circ} \mathrm{C}$ (between July and August), significant oscillations of the thermocline were observed, with clear differences between years. The 2017 summer presented deeper and warmer thermoclines compared to other years (Figure 6). The mean seawater temperature at $20 \mathrm{~m}$ in the 2017 summer was $23.04{ }^{\circ} \mathrm{C}$, which was higher than that of previous years $\left(2012=19.21{ }^{\circ} \mathrm{C} ; 2013=20.60{ }^{\circ} \mathrm{C} ; 2014=22.45^{\circ} \mathrm{C} ; 2015=20.06{ }^{\circ} \mathrm{C} ; 2016=\right.$ $22.75^{\circ} \mathrm{C}$ ). We found no significant correlation between bottom seawater temperature and the values of RSR, LP, CP, and MI (Spearman test, $p \geq 0.05$ ).

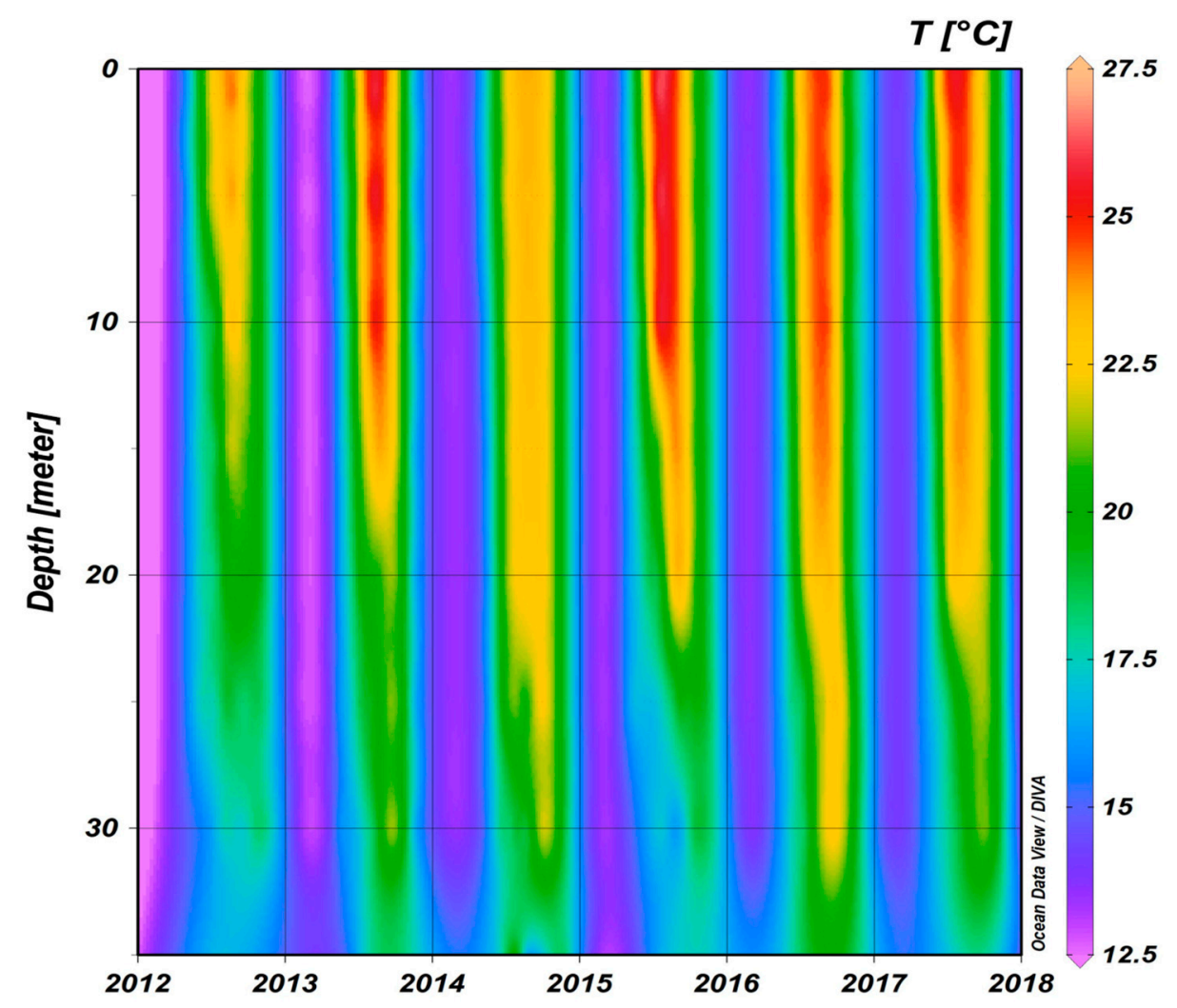

Figure 4. Stratification temperature maps showing the inter-annual variability of the temperature at the study site (the Calvi bay area) from March to September for the years from 2012 to 2017. 


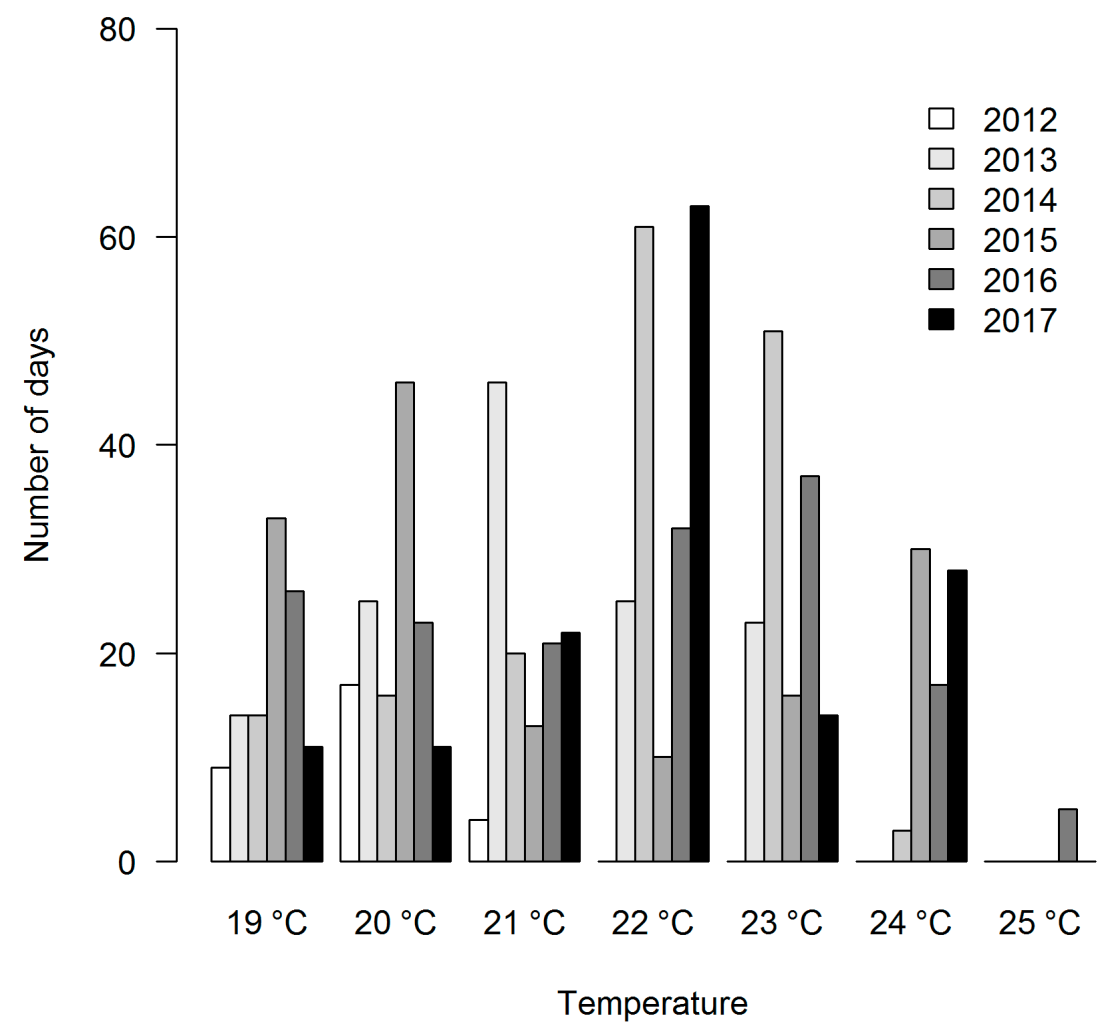

Figure 5. Total time (represented in days) per year that the temperature at 20 m exceeded the different temperature thresholds.

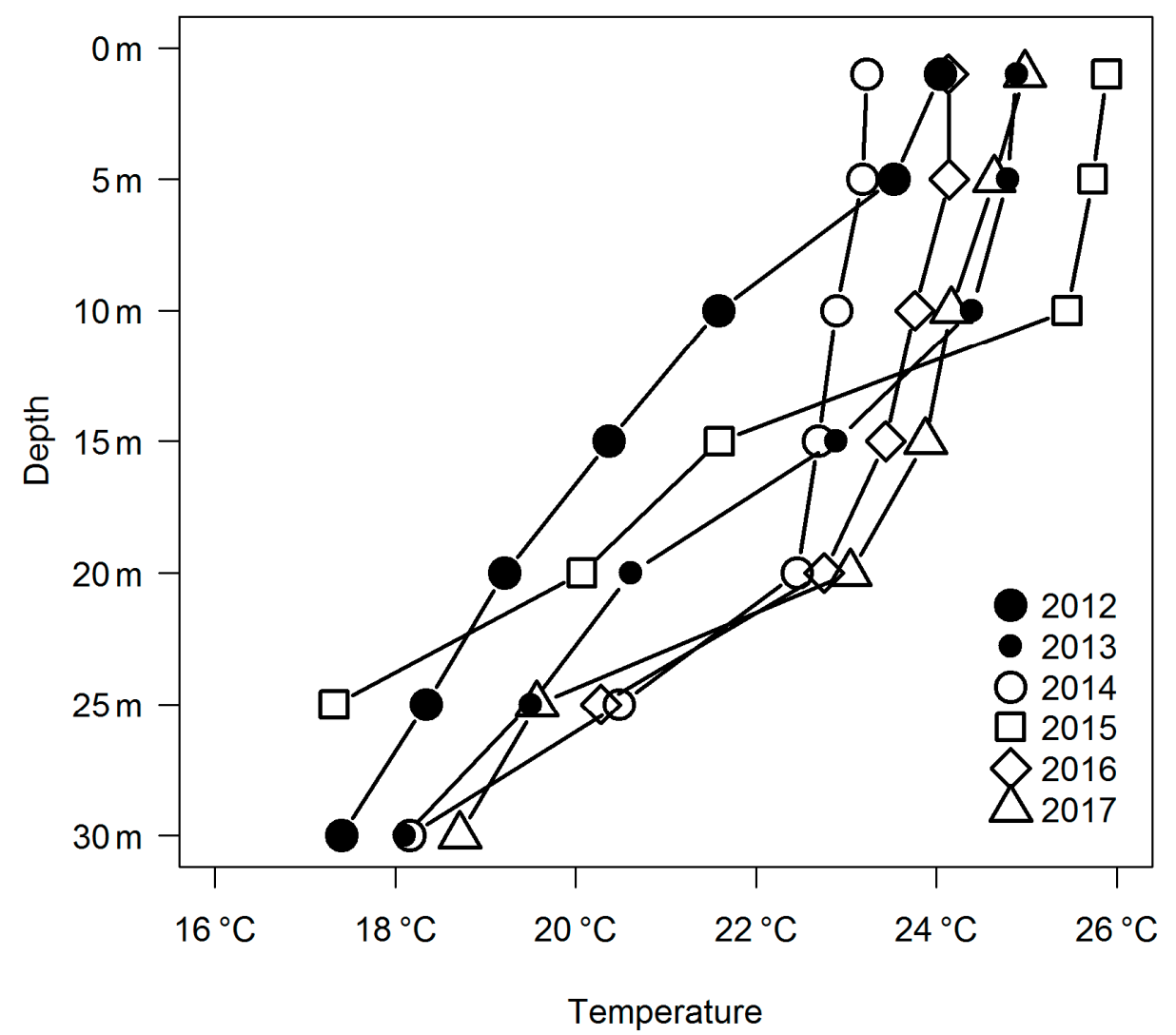

Figure 6. Summer (July/August) mean temperature in the Calvi bay area from 2012 to 2017. 


\section{Discussion}

In this study, the FAST indices showed spatial and temporal variations, with significant interannual variations but no seasonal changes (only spring and summer were tested in our dataset). Differences between areas were observed. Indeed, the indices varied greatly between the different areas, with high values in the Revellata zone and lower values in the two other sites. The Revellata zone had higher values of species richness, the most diversified trophic structure, and larger proportions of large individuals, which implies that this area exhibits favorable environmental conditions. Habitat differences, however, may have an effect, as they influence vertical and geographical differences between fish communities. The structure and complexity of the seascape of the Revellata zone are very high (rocky outcrops, sand, coralligenous, Posidonia oceanica meadows, etc.) compared to the complexity of the seascapes of the Saint-François and Spano zones [28]. Habitat structure is one of the factors that is likely to explain the variability in Mediterranean fish assemblages, at least for some species and assemblage parameters [29]. In our data, part of the observed variability in fish assemblage structure could be attributable to this factor. The seascape LIMA index corresponding to the richness of heritage species and the topographic quality, calculated for the same sites in the Calvi Bay area supports our results (Gobert et al., 2014): sites with high complexity have high richness.

The Revellata zone is located in the immediate vicinity $(<500 \mathrm{~m})$ of a fishery reserve, a marine protected area (cantonnement) of 1074 ha, created by ministerial decree on 20 June 1978. The variation in the structure of the fish assemblage and the observed differences could result from this protection status, as the Revellata zone may benefit from a "spillover effect". Fishing restrictions in the fishery reserve may result in to increase in the biomass of exploited species, which, under certain conditions, can promote spillover effects (export of biomass, net emigration of adults, and juveniles across borders) to the surrounding non-protected areas [30]. Conversely, indices values in the Spano zone were very low, as fish assemblage structure and composition were characterized by low species richness, total density, and fish body size.

The FAST method indicated a decrease in the proportion of large individuals (LP) within all three areas. Fishing pressure may have influenced this pattern. Previous studies have demonstrated that large individuals of commercially valuable species are primarily eliminated by fishing because they have the highest market value [31]. The intensity of anthropogenic disturbances, particularly from artisanal and recreational fisheries, may affect species directly (e.g., size patterns, age structure, distribution) or indirectly through interspecific interactions [32]. Changes in species-specific differential distributions could potentially alter interspecific interactions and food webs and exert significant impacts on fisheries [33].

Our results indicated a significant change in fish assemblage structure, with a general declining trend in the calculated indices. This decrease can be interpreted as the degradation of fish populations, as evidenced by the increase in the coefficient of variation (e.g., $\mathrm{CV}$ $+75 \%,+40 \%,+128 \%$ from 2012 to 2017 in the three zones). This pattern could be explained by numerous factors related to habitat and food preferences, social behavior, and natural occurrences [34]. Potential reasons for the decline include increased fishing, pollution, and changes in life-history traits, and seawater temperature [35].

Among all environmental factors, it is assumed that seawater temperature is the factor with the greatest effect on fish [36]. Species are sensitive to variations in seawater temperature at different stages of their lifecycle, which means that temperature effects are critical to the success of maturation, spawning, egg survival, and recruitment [37]. During the study period, we observed a typical thermal stratification (thermocline) for the northwestern Mediterranean Sea [38]. The oceanographic conditions in the Mediterranean are characterized in summer by high stability of the water column and high temperatures due to solar radiation, resulting in a strong stratification of the water column [39]. This permanent stratification, which begins in the spring, is reinforced during the summer. The thermocline is known to exhibit strong vertical oscillations over short periods, such as 
a few hours or days, which are mainly caused by wind, water masses movement, local hydrographic variations induced by the coastal orientation, and bathymetry [38].

Here, some temporal variations in fish assemblages could be explained by the warmer seawater in 2017 compared to previous years. In fact, the seawater temperature in the summer of 2017 was exceptionally high, with the temperature at $20 \mathrm{~m}$ exceeding $24^{\circ} \mathrm{C}$ for 28 days. Previous studies have revealed that the intensity of stratification of coastal waters, which produces longer and warmer summers due to global warming, occurs in the Northwestern Mediterranean Sea [39]. Several studies have demonstrated that changes in seawater temperature have direct effects on organisms' physiology and behavior, affecting growth, reproductive capacity, and mortality. Temperature changes also have indirect effects on the ecosystem, modifying population productivity, structure, and composition [40]. In recent years, changes in fish distribution have been described, with depths generally changing as fish follow their optimal temperature range [41]. Some species may migrate to other areas, and some move to deeper water, including under the thermocline [42]. The increase in seawater temperature may have prompted some species to migrate to deeper waters. These deeper waters have been able to serve as refuge areas for these particularly sensitive and vulnerable species, especially larger fishes.

This study does provide evidence that species assemblages are influenced by different factors. The response of the fish was clear and significant and tended to decrease over time at the three sites, but no significant differences between the seasons were observed. Even if different hypotheses have been put forward to explain these variations, we would like to remind you that, in our case study, only the predictor variables "Year", "Location", and "Season" were tested in our dataset. These differences observed are real, they exist, but our results did not allow us to fully discriminate their origins. They are certainly multiparametric and multifactorial, and additional research is needed to explain these variations. To continue this process and improve results, measurements of additional abiotic and biotic factors that are closely associated with fish communities would be needed. These parameters can be used to refine explanatory models between fish communities and environmental variables. Taking continuous high-frequency measurements at different depths using a data logger would allow a more precise interpretation of the water temperature. In addition, there may be a cumulative and synchronous effect of the multiple stressors of anthropic and/or natural origins that can disturb the equilibrium within these assemblages [43]. Thus, it is necessary to better understand how these factors interact with each other and affect the variability of natural populations. The combination of traditional sampling methods and innovative emerging technologies, such as remote sensing, echo-sounder transects, bioacoustics, or even environmental DNA metabarcoding would provide a more holistic view of marine communities. Therefore, the combined use of complementary methods would provide a more complete picture of biodiversity. This information could therefore have major implications for the conservation of species. It is recognized that long-term monitoring at the community level is necessary and crucial to better understand the nature and extent of these impacts [44]. Given the current situation, future continuous monitoring at the community level is needed throughout the Mediterranean area.

Author Contributions: Conceptualization, M.M. and P.L.; methodology, M.L.; software, M.M., L.I.; validation, L.I., M.L., S.G., P.B. and P.L.; formal analysis, M.M.; resources, P.B.; data curation, M.M.; writing-original draft preparation, M.M.; writing-review and editing, S.G.; visualization, L.I.; supervision, S.G., P.L.; project administration, P.L.; funding acquisition, P.L. All authors have read and agreed to the published version of the manuscript.

Funding: This research was funded by the "Agence de l'eau Rhône Méditerranée Corse" and the "Collectivité de Corse" (CdC), as part of STARECAPMED project research.

Institutional Review Board Statement: Not applicable.

Data Availability Statement: The data presented in this study are available on request from the corresponding author. 
Acknowledgments: This manuscript is dedicated to the memory of Patrice Francour. Special thanks are extended to the STARESO team (Annick Donnay, Quentin Fontaine, Lovina Fullgrabe, David Lorieux, Michela Patrissi, Corinne Pelaprat, Tatiana Severin) for valuable discussions and their collaboration.

Conflicts of Interest: The authors declare no conflict of interest.

\section{References}

1. Abdul Malak, D.; Livingstone, S.R.; Pollard, D.; Polidoro, B.A.; Cuttelod, A.; Bariche, M.; Bilecenoglu, M.; Carpenter, K.E.; Collette, B.B.; Francour, P.; et al. Overview of the Conservation Status of the Marine Fishes of the Mediterranean Sea; IUCN: Gland, Switzerland; Malaga, Spain, 2011; p. 61.

2. Jackson, J.B.; Kirby, M.X.; Berger, W.H.; Bjorndal, K.A.; Botsford, L.W.; Bourque, B.J.; Bradbury, R.H.; Cooke, R.; Erlandson, J.; Estes, J.A. Historical Overfishing and the Recent Collapse of Coastal Ecosystems. Science 2001, 293, 629-637. [CrossRef] [PubMed]

3. Schiel, D.R.; Steinbeck, J.R.; Foster, M.S. Ten Years of Induced Ocean Warming Causes Comprehensive Changes in Marine Benthic Communities. Ecology 2004, 85, 1833-1839. [CrossRef]

4. Currie, D.R.; Parry, G.D. Changes to Benthic Communities over 20 Years in Port Phillip Bay, Victoria, Australia. Mar. Pollut. Bull. 1999, 38, 36-43. [CrossRef]

5. Hiddink, J.; Ter Hofstede, R. Climate Induced Increases in Species Richness of Marine Fishes. Glob. Chang. Biol. 2008, 14, 453-460. [CrossRef]

6. Le Quesne, W.J.; Pinnegar, J.K. The Potential Impacts of Ocean Acidification: Scaling from Physiology to Fisheries. Fish Fish. 2012, 13, 333-344. [CrossRef]

7. Mallet, D.; Wantiez, L.; Lemouellic, S.; Vigliola, L.; Pelletier, D. Complementarity of Rotating Video and Underwater Visual Census for Assessing Species Richness, Frequency and Density of Reef Fish on Coral Reef Slopes. PLoS ONE 2014, 9, e84344. [CrossRef] [PubMed]

8. La Mesa, G.; Micalizzi, M.; Giaccone, G.; Vacchi, M. Cryptobenthic Fishes of the "Ciclopi Islands" Marine Reserve (Central Mediterranean Sea): Assemblage Composition, Structure and Relations with Habitat Features. Mar. Biol. 2004, 145, 233-242. [CrossRef]

9. Pinnegar, J. Why the Damselfish Chromis Chromis Is a Key Species in the M Editerranean Rocky Littoral-A Quantitative Perspective. J. Fish Biol. 2018, 92, 851-872. [CrossRef] [PubMed]

10. Lamine, E.B.; Di Franco, A.; Romdhane, M.S.; Francour, P. Can Citizen Science Contribute to Fish Assemblages Monitoring in Understudied Areas? The Case Study of Tunisian Marine Protected Areas. Estuar. Coast. Shelf Sci. 2018, 200, 420-427. [CrossRef]

11. Bell, J.; Craik, G.; Pollard, D.; Russell, B. Estimating Length Frequency Distributions of Large Reef Fish Underwater. Coral Reefs 1985, 4, 41-44. [CrossRef]

12. Bacheler, N.M.; Geraldi, N.R.; Burton, M.L.; Muñoz, R.C.; Kellison, G.T. Comparing Relative Abundance, Lengths, and Habitat of Temperate Reef Fishes Using Simultaneous Underwater Visual Census, Video, and Trap Sampling. Mar. Ecol. Prog. Ser. 2017, 574, 141-155. [CrossRef]

13. Davis, T.; Harasti, D.; Smith, S.D. Compensating for Length Biases in Underwater Visual Census of Fishes Using Stereo Video Measurements. Mar. Freshw. Res. 2015, 66, 286-291. [CrossRef]

14. Samoilys, M.A.; Carlos, G. Determining Methods of Underwater Visual Census for Estimating the Abundance of Coral Reef Fishes. Environ. Biol. Fishes 2000, 57, 289-304. [CrossRef]

15. Edgar, G.J.; Barrett, N.S.; Morton, A.J. Biases Associated with the Use of Underwater Visual Census Techniques to Quantify the Density and Size-Structure of Fish Populations. J. Exp. Mar. Biol. Ecol. 2004, 308, 269-290. [CrossRef]

16. Edgar, G.J.; Stuart-Smith, R.D. Ecological Effects of Marine Protected Areas on Rocky Reef Communities-A Continental-Scale Analysis. Mar. Ecol. Prog. Ser. 2009, 388, 51-62. [CrossRef]

17. Pais, M.P.; Cabral, H.N. Effect of Underwater Visual Survey Methodology on Bias and Precision of Fish Counts: A Simulation Approach. PeerJ 2018, 6, e5378. [CrossRef] [PubMed]

18. De Girolamo, M.; Mazzoldi, C. The Application of Visual Census on Mediterranean Rocky Habitats. Mar. Environ. Res. 2001, 51, 1-16. [CrossRef]

19. Katsanevakis, S.; Weber, A.; Pipitone, C.; Leopold, M.; Cronin, M.; Scheidat, M.; Doyle, T.K.; Buhl-Mortensen, L.; Buhl-Mortensen, P.; Anna, G. Monitoring Marine Populations and Communities: Methods Dealing with Imperfect Detectability. Aquat. Biol. 2012, 16, 31-52. [CrossRef]

20. Williams, I.D.; Richards, B.L.; Sandin, S.A.; Baum, J.K.; Schroeder, R.E.; Nadon, M.O.; Zgliczynski, B.; Craig, P.; McIlwain, J.L.; Brainard, R.E. Differences in Reef Fish Assemblages between Populated and Remote Reefs Spanning Multiple Archipelagos across the Central and Western Pacific. J. Mar. Biol. 2011, 2011, 1-14. [CrossRef]

21. García-Charton, J.; Pérez-Ruzafa, A. Spatial Pattern and the Habitat Structure of a Mediterranean Rocky Reef Fish Local Assemblage. Mar. Biol. 2001, 138, 917-934. [CrossRef]

22. Caldwell, Z.R.; Zgliczynski, B.J.; Williams, G.J.; Sandin, S.A. Reef Fish Survey Techniques: Assessing the Potential for Standardizing Methodologies. PLoS ONE 2016, 11, e0153066. [CrossRef]

23. Francour, P.; Liret, C.; Harvey, E. Comparison of Fish Abundance Estimates Made by Remote Underwater Video and Visual Census. Nat. Sicil. 1999, 23, 155-168. 
24. Harmelin-Vivien, M.; Harmelin, J.; Chauvet, C.; Duval, C.; Galzin, R.; Lejeune, P.; Barnabé, G.; Blanc, F.; Chevalier, R.; Duclerc, J. Evaluation Visuelle Des Peuplements et Populations de Poissons Méthodes et Problèmes. Revue D'écologie 1985, 40, 467-539.

25. Dickens, L.C.; Goatley, C.H.; Tanner, J.K.; Bellwood, D.R. Quantifying Relative Diver Effects in Underwater Visual Censuses. PLoS ONE 2011, 6, e18965. [CrossRef] [PubMed]

26. Seytre, C.; Francour, P. The Cap Roux MPA (Saint-Raphael, French Mediterranean): Changes in Fish Assemblages within Four Years of Protection. ICES J. Mar. Sci. J. Du Cons. 2009, 66, 180-187. [CrossRef]

27. Seytre, C.; Francour, P. Is the Cape Roux Marine Protected Area (Saint-Raphaël, Mediterranean Sea) an Efficient Tool to Sustain Artisanal Fisheries? First Indications from Visual Censuses and Trammel Net Sampling. Aquat. Living Resour. 2008, 21, 297-305. [CrossRef]

28. Gobert, S.; Chéry, A.; Volpon, A.; Pelaprat, C.; Lejeune, P. The seascape as an indicator of environmental interest and quality of the Mediterranean benthos: The in situ development of a description index: The LIMA. In Underwater Seascapes; Springer: Berlin/Heidelberg, Germany, 2014; pp. 277-291.

29. García-Charton, J.A.; Pérez-Ruzafa, Á.; Sánchez-Jerez, P.; Bayle-Sempere, J.T.; Reñones, O.; Moreno, D. Multi-Scale Spatial Heterogeneity, Habitat Structure, and the Effect of Marine Reserves on Western Mediterranean Rocky Reef Fish Assemblages. Mar. Biol. 2004, 144, 161-182. [CrossRef]

30. Lizaso, J.S.; Goni, R.; Renones, O.; Charton, J.G.; Galzin, R.; Bayle, J.; Jerez, P.S.; Ruzafa, A.P.; Ramos, A. Density Dependence in Marine Protected Populations: A Review. Environ. Conserv. 2000, 27, 144-158. [CrossRef]

31. Pauly, D.; Christensen, V.; Dalsgaard, J.; Froese, R.; Torres, F. Fishing down Marine Food Webs. Science 1998, $279,860-863$. [CrossRef]

32. Genner, M.J.; Sims, D.W.; Southward, A.J.; Budd, G.C.; Masterson, P.; Mchugh, M.; Rendle, P.; Southall, E.J.; Wearmouth, V.J.; Hawkins, S.J. Body Size-dependent Responses of a Marine Fish Assemblage to Climate Change and Fishing over a Century-long Scale. Glob. Chang. Biol. 2010, 16, 517-527. [CrossRef]

33. Cheung, W.W.; Lam, V.W.; Sarmiento, J.L.; Kearney, K.; Watson, R.; Pauly, D. Projecting Global Marine Biodiversity Impacts under Climate Change Scenarios. Fish Fish. 2009, 10, 235-251. [CrossRef]

34. Claudet, J.; Osenberg, C.W.; Domenici, P.; Badalamenti, F.; Milazzo, M.; Falcón, J.M.; Bertocci, I.; Benedetti-Cecchi, L.; GarcíaCharton, J.A.; Goñi, R.; et al. Marine Reserves: Fish Life History and Ecological Traits Matter. Ecol. Appl. 2010, 20, 830-839. [CrossRef]

35. Gaspare, L.; Bryceson, I.; Mgaya, Y. Temporal and Spatial Trends in Size, Biomass and Abundance of Groupers (Epinephelinae) in Mafia Island Marine Park: Fishers' Perceptions and Underwater Visual Census Surveys. Fish. Manag. Ecol. 2015, 22, 337-348. [CrossRef]

36. Teixeira, C.M.; Gamito, R.; Leitão, F.; Cabral, H.N.; Erzini, K.; Costa, M.J. Trends in Landings of Fish Species Potentially Affected by Climate Change in Portuguese Fisheries. Reg. Environ. Chang. 2014, 14, 657-669. [CrossRef]

37. Somarakis, S.; Ramfos, A.; Palialexis, A.; Valavanis, V.D. Contrasting Multispecies Patterns in Larval Fish Production Trace Inter-Annual Variability in Oceanographic Conditions over the N.E. Aegean Sea Continental Shelf (Eastern Mediterranean). Hydrobiologia 2011, 670, 275-287. [CrossRef]

38. Bensoussan, N.; Romano, J.-C.; Harmelin, J.-G.; Garrabou, J. High Resolution Characterization of Northwest Mediterranean Coastal Waters Thermal Regimes: To Better Understand Responses of Benthic Communities to Climate Change. Estuar. Coast. Shelf Sci. 2010, 87, 431-441. [CrossRef]

39. Coma, R.; Ribes, M.; Serrano, E.; Jimenez, E.; Salat, J.; Pascual, J. Global Warming-Enhanced Stratification and Mass Mortality Events in the Mediterranean. Proc. Natl. Acad. Sci. USA 2009, 106, 6176-6181. [CrossRef]

40. Perry, A.L. Climate Change and Distribution Shifts in Marine Fishes. Science 2005, 308, 1912-1915. [CrossRef] [PubMed]

41. Lejeusne, C.; Chevaldonné, P.; Pergent-Martini, C.; Boudouresque, C.F.; Pérez, T. Climate Change Effects on a Miniature Ocean: The Highly Diverse, Highly Impacted Mediterranean Sea. Trends Ecol. Evol. 2010, 25, 250-260. [CrossRef] [PubMed]

42. Masuda, R. Seasonal and Interannual Variation of Subtidal Fish Assemblages in Wakasa Bay with Reference to the Warming Trend in the Sea of Japan. Environ. Biol. Fishes 2008, 82, 387-399. [CrossRef]

43. Brander, K. Tackling the Old Familiar Problems of Pollution, Habitat Alteration and Overfishing Will Help with Adapting to Climate Change. Mar. Pollut. Bull. 2008, 56, 1957. [CrossRef] [PubMed]

44. Halpern, B.S.; Cottenie, K. Little Evidence for Climate Effects on Local-scale Structure and Dynamics of California Kelp Forest Communities. Glob. Chang. Biol. 2007, 13, 236-251. [CrossRef] 